STRATEGIC ALLIANCES AND COMPETITIVE STRATEGIES IN THE EUROPEAN AEROSPACE INDUSTRY: THE CASE OF BMW ROLLSROYCE GmbH

\author{
D.J.Smith \\ Nottingham Trent University
}

Address for Correspondence:

Professor David J. Smith

Nottingham Business School

Nottingham Trent University

Burton Street

Nottingham

NG1 4BU

UK

Tel. $\quad 00441158484745$

Fax. 00441158484707

Email David.Smith02@ntu.ac.uk 


\begin{abstract}
Strategic alliances are an important feature of the aerospace industry and there have been many studies that have sought to evaluate their performance. Most have taken a policy perspective exploring the economic and political benefits claimed for collaboration of this type. The perspective is a reflection of the political origins of many aerospace alliances. This study seeks to evaluate, from a managerial perspective, one of the newer alliances established on a strictly commercial basis,. It focuses on BMW Rolls-Royce $\mathrm{GmbH}$, one of a small number of truly European alliances. The study concludes that although Rolls-Royce bought out its German partner after a decade of operation, the alliance was a success. The two engines developed by the alliance over this period were a technical success, overall sales were well on target and the alliance was about to break even. In addition, the study concludes that the alliance formed a key element in Rolls-Royce's successful strategy to extend its product portfolio, a strategy that elevated the company to second place in the global aero engine market.
\end{abstract}

Keywords: Aerospace; Competitive Strategy; Strategic Alliances; Performance. 


\section{STRATEGIC ALLIANCES AND COMPETITIVE STRATEGIES IN THE EUROPEAN AEROSPACE INDUSTRY: THE CASE OF BMW ROLLS- ROYCE GmbH}

\section{INTRODUCTION}

Cross border collaboration through international joint ventures has become increasingly common (Dussauge and Garrette, 1999), forming an intermediate step between markets and hierarchies (Gomes-Casseres, 1996) as a means of achieving economic coordination. Collaboration has particularly been a feature of high technology industries and several studies (Hartley and Martin, 1990; Hegert and Morris, 1988; Glaister and Buckley, 1994) have shown that aerospace is an industry with one of the highest rates of international joint venture formation. Such ventures have a long history in aerospace, having been a feature of the industry in Europe since the 1960s.

Although the aircraft manufacuring sector of the aerospace industry is home to some of the best known examples of aerospace collaboration such as Airbus Industrie, Panavia and Eurofighter, joint ventures are also widespread in the aero engine sector. Unlike their counterparts in the aircraft manufacturing sector, most are commercial joint ventures, established by the engine manufacturers themselves rather than at the behest of governments. Among the better known ones are CFM-International, a joint venture between General Electric of the US and France's SNECMA, and International Aero Engines a joint venture between Pratt and Whitney of the US, Britain's RollsRoyce, MTU of Germany and a Japanese consortium. More recently the two leading US engine makers have together formed a joint venture to develop a new engine for the new high capacity Airbus A380. As well as these alliances that produce engines for the civil airliner market are ones set up to produce smaller commercial engines. In this category comes Williams-Rolls, a joint venture between Williams International of the US and Rolls-Royce, that produces the FJ44 engine for small business jets, and until recently, BMW Rolls-Royce GmbH, a joint venture set up to produce the BR700 engine, for large business jets and regional airliners. 
BMW Rolls-Royce GmbH was established on $1^{\text {st }}$ July 1990 as a joint venture between the German car maker BMW AG (50.5\%) and Britain's Rolls-Royce (49.5\%). The purpose of the joint venture was to develop a new engine core, the BR700, that would provide the basis of a family of engines covering the $12,000-14,000 \mathrm{lbs}$ thrust market segment and designed to replace Rolls-Royce's successful Tay engine. From its inception, BMW Rolls-Royce $\mathrm{GmbH}$ was an unusual joint venture.

Firstly BMW Rolls-Royce GmbH is the only aerospace alliance with a partner drawn from outside the aerospace industry. Although BMW began life as a manufacturer of aero engines (Monnich, 1991) and was Germany's leading producer of jet engines in World War 2 (Kay, 1993), it severed its links with aerospace in the 1960s and by 1990 its activities were confined to the automotive industry. While there have been other instances of firms using joint ventures to gain market entry, they have always had existing aerospace interests. Secondly, BMW Rolls-Royce GmbH was a separate entity, with a higher degree of independence from its parents than other joint ventures. The partners in CFM-International, General Electric of the US and France's Snecma, for instance, are each responsible for assembling engines produced by the joint venture, while BMW Rolls-Royce GmbH established its own purpose-built manufacturing and assembly facilities at Dahlewitz near Berlin. This led Dussauge and Garrette (1995) in a taxonomy of collaborative agreements, to classify BMW Rolls-Royce $\mathrm{GmbH}$ in a different category from other engine joint ventures, termed 'Business-based joint ventures'. Finally, BMW Rolls-Royce GmbH is unusual in that it is the only commercial aero engine joint ventures where both of the partners are European. All the others have been transatlantic alliances, with the partners drawn from both sides of the atlantic. BMW Rolls-Royce is unique in being an entirely European joint venture, created by European companies as a commercial venture, without any government involvement. This factor alone makes it worthy of study.

This paper reports on a study that aims to evaluate this example of European collaboration in the aerospace industry. Unlike other studies of aerospace strategic alliances, this study takes a strategic perspective rather than a policy perspective, evaluating performance in terms of the contribution of the joint venture to the long term aims of the partners and the specific objectives identified for the joint venture 
itself. It includes an examination of the part played by each of the partners. This provides an opportunity to examine the role of this strategic alliance in helping the partner organisations implement their competitive strategies. This in turn helps to explain the reasons behind the announcement in November 1999 that Rolls-Royce was to buy out BMW's stake effectively ending ten years of joint venture operation, although the joint venture continues to function as Rolls-Royce Deutschland.

\section{ANALYTICAL FRAMEWORK}

The scale of the collaborative activity in the aerospace industry has resulted in it being the focus of a number of research studies. Many of these have sought to evaluate the performance of international joint ventures in aerospace. However as Dussauge and Garrette (1993) point out, these studies have generally taken an economic or political perspective, rather than a managerial perspective.

Studies that have been primarily economic (Hartley, 1983; Hartley, 1988; Mowery, 1988; Martin and Hartley, 1991; Hartley and Martin, 1993; Martin and Hartley, 1995) have sought to evaluate public policy in terms of the efficient allocation of resources. Although some of the studies have included joint ventures covering civil aerospace, the focus has generally been on military programmes especially those described by Muller (1995, p176) as, 'alliances imposed by governments', rather than commercial joint ventures. Evaluation focussed upon economic efficiency, with performance judged in terms of cost savings, increases in output and the level of exports. The studies have generally taken the form of quantitative studies and their findings have pointed to increased market share for European collaborative programmes but at the cost of longer development times (Martin and Hartley, 1991) and higher production costs (Martin and Hartley, 1995) compared to independent national programmes.

Alongside studies that have sought to make an economic evaluation, have been those taking a political perspective (Hayward, 1976; Mowery, 1987; Thornton, 1996; Muller, 1995; McGuire, 1997). Though diverse in their aims, they too have generally sought to evaluate policies. Among the themes covered have been economic 
integration, trade policy, the role of the state and industrial/competition policy. Again the focus has been less on the operation of individual joint ventures and more on the impact upon policy. They have endeavoured to evaluate policy decisions, but from a political rather than an economic perspective.

In contrast to the substantial number of studies that have concentrated on economic/political aspects of joint ventures there have been only a very small number (Dussauge and Garrette, 1993; Dussauge and Garrette, 1994; Dussauge and Garrette, 1995) that have sought to evaluate collaborative arrangements from a strategic management perspective. This is probably a reflection of the political origins of many of the older alliances. Commercial joint ventures are a more recent phenomenon, so there are fewer of them and consequently they have been subject to less scrutiny. The few studies that have been undertaken link commercial success to the organisational structures adopted.

This study endeavours to assist in redressing this imbalance in particular the lack of studies that have taken a strategic management perspective. It is based on an evaluation of one of the newer forms of alliance, namely a commercial, rather than a politically inspired, joint venture. It is also one of a comparatively small number of studies to be based on a single detailed case study rather than a quantitative study covering a large number of different programmes.

\section{THE PERFORMANCE OF THE JOINT VENTURE}

\section{Aims and Objectives}

Whereas economic and political evaluations of joint ventures can take a broad perspective exploring issues such as allocative efficiency, evaluations from a strategic management perspective need to be more focussed. Where commercial joint ventures such as BMW Rolls-Royce GmbH are concerned, commercial aims provide the primary focus for the joint venture's activities. Wider economic and political considerations are inevitably of less concern to partners in commercial joint ventures. 
In the case of BMW Rolls-Royce $\mathrm{GmbH}$, the principal commercial aim was to establish the joint venture as a leading European manufacturer of aero engines within two specific segments of the aero engine market, namely large corporate jets and regional airliners. It was also hoped to secure some re-engining applications on older jets.

\section{Take in Table I}

A simple comparison of BMW Rolls-Royce's turnover after almost a decade of operation, with other European engine makers indicates that this objective was achieved. Table I shows that by 1999 when Rolls-Royce took over the joint venture, BMW Rolls-Royce GmbH had become a major European aero engine manufacturer. In the space of ten years it had grown into a business with a turnover of nearly threequarters of a billion dollars. It had overtaken France's Turbomeca, a long established manufacturer of small aero engines. The joint venture's progress was all the more impressive when one considers that some of its rivals, such as SNECMA, Volvo Flygmotor and Fiat Avio manufactured aerospace components as well as engines. A measure of the joint venture's international success can be gauged by the fact that BMW Rolls-Royce GmbH became one of the Top 100 Aerospace companies in the world in 1998 , in $75^{\text {th }}$ position measured by turnover, rising in the following year to $50^{\text {th }}$ place. Furthermore BMW Rolls-Royce GmbH had only delivered its first engine three years earlier in 1996.

Thus by the end of the 1990s, the principal strategic aim of the joint venture had been achieved. This was a considerable achievement bearing in mind that the partners anticipated a relatively slow build-up to full production given the long term nature of the aerospace industry. However evaluating a joint venture from a strategic management perspective also demands that some of the more specific objectives be considered.

\section{Production}

The joint venture's aim of becoming one of Europe's leading manufacturers of aero engines for civil aircraft was to be achieved by means of a new generation of engines 
based around the development of a new engine core. The BR700 core engine was formally launched on $31^{\text {st }}$ March 1991. It drew heavily on Rolls-Royce's other engine programmes (Rupertson, 1998). The new core was run successfully for the first time in August 1993.

\section{Take in Figure 1}

The entry of the BR710 engine into service in late 1996 marked the transition of BMW Rolls-Royce GmbH from a company that developed aero engines to one that manufactured them. As figure 1 shows, production built up rapidly. Output in 1997 was 100 engines, all BR710 engines for Gulfstream V corporate jets. The following year in 1998, production of engines for the Global Express corporate jet commenced. In 1999 the larger BR715 engine went into production and entered service on the Boeing 717-200 regional jet. These developments reflected a rapid build up in production. Figure 1 shows that by 1999 production had almost doubled to 200 engines per year. In the same year the joint venture moved up to three shift operation. Thus by 1999 the objective of developing a new engine core that could be used as the basis of a family of new engines had been achieved, and two engines, the 14,000lbs thrust BR710 and the 18,000lbs thrust BR715, had been designed, developed, certificated and put into service.

\section{Sales}

In terms of sales, BMW Rolls-Royce GmbH also performed well. By late 1999, nearly ten years after the joint venture was first announced, BMW Rolls-Royce GmbH had orders for 1,000 engines. This compares with projected sales of 3,000 for the period 1996-2010. The first engine in the BR700 series, the 14,000lbs thrust BR710 was launched in 1992 . Production commenced in1996 and this was quickly reflected in the joint venture's turnover. As table II shows turnover increased tenfold in the four years between 1995 and 1999. Hence BMW Rolls-Royce GmbH had achieved one third of its targeted sales within a comparatively short space of time and was well on target to achieve the sales total planned for 2010 . 


\section{Take in Table II}

Not only was the level of total engine orders strong, the joint venture had by 1999 notched up these sales on four different aircraft applications. These included the Gulfstream V corporate jet, the Global Express corporate jet, the Boeing 717-200 (formerly designated the MD-95) 100 seat regional airliner and the British Aerospace Nimrod 2000 maritime patrol aircraft. In addition, all four of these applications were single sourced. That is to say in each instance the BMW Rolls-Royce GmbH engine was the only one used on that airframe. There was no rival engine that customers could specify. Although single sourcing is more likely to occur with corporate jet and regional airliner applications (Bonaccorsi and Giuri, 2000) because customers do not have large aircraft fleets that justify multiple sourcing, nonetheless this was impressive. It was a measure of the airframe manufacturers confidence in the new engine and also pointed to the prospect of greater profitability for the BR700 series engine because of the absence of competition.

While the joint venture proved successful in terms of its technical ability to develop new engines, and the overall level of sales was well on target by the late 1990s, the penetration of specific market segments did not turn out as planned when the joint venture was established in 1990.

\section{Corporate jets}

The joint venture's business plan envisaged sales of 3000 engines over the period 1996-2010. Having achieved orders for 1000 engines by 1999, BMW Rolls-Royce $\mathrm{GmbH}$ was well on target. However the mix of engines envisaged that the 3000 engines would be split in favour of the regional jet market with only 700 engines being sold in the corporate jet market. In reality the split was the other way round with the corporate jet sector taking two-thirds of BMW Rolls-Royce GmbH's sales. This pattern reflected greater than expected success in the corporate jet sector and disappointing results in the regional jet market. BMW Rolls-Royce GmbH's success in corporate jets came early. Having the BR710 engine selected by both of the manufacturers of a new generation of ultra-long range, 'heavy iron' (Phillips, Phillips 
and Phillips, 1994) corporate jets meant that the joint venture dominated this market segment.

\section{The Re-engining market}

The second market that the joint venture planned to target when it was formed in 1990 was the re-engining market. This was a market in which Rolls-Royce's Tay engine had enjoyed considerable success. As new Stage 3 noise regulations came into operation in the late 1980s operators of first generation short haul airliners such as the Boeing 727 and the BAC1-11 found that re-equiping these aircraft with Rolls-Royce's Tay engine was a cost effective solution to the problem of noise compliance. Reengining with the Tay engine offered the twin benefits of a proven engine with which operators were already familiar, combined with the latest developments in technology such as Rolls-Royce's wide chord fan (Kinnear, 1986). Since the BR710 was technically more advanced than the Tay engine it was hoped that operators would opt for the new engine. Although a number of re-engining applications were proposed, including a recent proposal to re-engine the MD-80 twin jet with the BR715 engine (Kingsley-Jones, 2001b), no commercial applications had been forthcoming by the time Rolls-Royce bought out BMW's stake at the end of 1999. Instead most aircraft operators opted instead for 'hushkits' that made existing engines noise compliant.

However BMW Rolls-Royce GmbH did achieve one re-engining success and it came from an unlikely source, the defence sector. When in 1997 Britain's Ministry of Defence decided to upgrade the Royal Navy's maritime patrol aircraft, the Nimrod, BMW Rolls-Royce GmbH won an order for 88 BR710 engines (BMW, 1998, p91) as part of a re-engining programme.

\section{The Regional Jet market}

By the time Rolls-Royce came to buy out BMW's share in November 1999, the joint venture had enjoyed only limited success in the regional jet market. When the joint venture was founded in 1990 there were strong signs of the potential of the regional airliner market. Regional airline traffic in the US had grown fourfold during the 1980s in the aftermath of de-regulation (Hanlon, 1996). A particular feature of the growth was the spread of alliances and partnerships between major US airlines and 
smaller regional airlines. These alliances, some of which took the form of franchising arrangements, were designed to consolidate traffic feed and extend networks. By 1990 a similar trend was beginning in Europe with regional airlines expanding more rapidly than the airline industry as a whole. However, the regional airliner market was still dominated, as figure 2 makes plain, by more fuel efficient if less comfortable small turboprop powered aircraft. This domination reflected the fact that the 30-50 seat segment of the market was almost exclusively the preserve of turboprop aircraft. What is more a number new turboprop aircraft appeared in the 1980s powered by new turboprop engines that gave a marked improvement in performance (Bonaccorsi and Giuri, 2000). A number of jet powered regional airliners in the 100 seat market segment had been proposed including Daimler-Benz Aerospace's Regioliner, the Aerospatiale/Alenia AI(R) 70 and the Fokker 70. All were European offerings and there were a number of Asian proposals at this time as well. Under the circumstances the prospects for 100 seat regional jets looked promising and the BR715 engine was targeted at this market segment.

\section{Take in Figure 2}

During the 1990s, the regional aircraft market underwent what Bonaccorsi and Giuri, (2000, p857) describe as a 'radical change'. The catalyst for this change was Bombardier's introduction of a 50 seat regional jet the CRJ100/200, a derivative of the company's successful Challenger 601 business jet originally designed by Bill Lear (Phillips, Phillips and Phillips, 1994, p124) the originator of the Learjet. Bombardier's new regional jet was followed by similar offerings from Embraer and FairchildDornier. Like Bombardier's regional jet they too were derivatives of existing models. Both were derivatives not of business jets but turboprop powered regional airliners. All three designs, while powered by turbofan engines, because of their small size, utilized engines much smaller than those offered by BMW Rolls-Royce GmbH. Both the CRJ100/200 and the Embraer ERJ 145 proved highly popular. By the end of the 1990s Bombardier had orders for 730 CRJ100/200s, of which 417 were in service and Embraer had orders for 737 ERJ 145s of which 286 were in service (Flight International,2000b). As figure 2 shows the regional airliner market shifted 
dramatically from turboprop to turbofan powered aircraft, causing what many described as a 'rush for jets'.

Meanwhile the larger 100 seat regional airliner designs proposed in the late 1980s failed to materialize. One by one the projects were cancelled. Then in 1996 Fokker, the aircraft manufacturer that had pioneered the regional jet with its F28 back in the 1970s and been a major customer for the BR700's predecessor, the Rolls-Royce Tay engine, ceased trading. At this point the market for engines of the BR715's thrust rating looked bleak. BMW Rolls-Royce $\mathrm{GmbH}$ found its claim to the regional jet market squeezed from three directions, despite the fact that the overall market grew rapidly in the 1990s. The demise of most of the 100 seat regional jet designs proposed in the late 1980s, combined with the departure of Fokker, one of Rolls-Royce's biggest customers for the Tay engine, deprived the joint venture of a number of potential airframe applications. At the same time the market for small turbofan engines expanded dramatically as new 50 seat regional jets appeared. One of the main beneficiaries was General Electric with its CF34 engine. Having established a firm bridgehead, the manufacturers of these small regional jets were then able to trade up and enter the 70 seat market segment. Bombardier's CRJ700 model which was launched in the late 1990s, was a stretched version of its earlier CRJ100/200 design. Fairchild Dornier and Embraer came up with entirely new designs. As General Electric developed more powerful versions of the CF34 engine, manufacturers like Bombardier opted for manufacturers they knew and worked with previously. Unfortunately up-rating engines tends to be a more attractive proposition than derating them, so that BMW Rolls-Royce GmbH effectively missed out on the 'rush to jets' that occurred in the regional airliner market in the 1990s.

\section{Take in Table III}

The joint venture was only able to achieve one regional jet application, the MD-95 later re-designated as the Boeing 717. Although this was a single sourcing application, by the end of the 1990s sales of the Boeing 717 which entered service with AirTran Airways in September 1999 proved disappointing. Table III shows that by 2001 total sales of the Boeing 717 came to 150. By comparison Bombardier's CRJ700, which 
had yet to enter service, had orders for 222 aircraft by May 2000 (Dixon, 2000). This was a reflection of the popularity of smaller jets. Reluctant to incur the cost of a new variant and worried that the development of a second version would hit sales of its 100 seat model, Boeing did not develop a 70 seat variant. As a result BMW RollsRoyce $\mathrm{GmbH}$ was effectively shut out of the market for regional jets in the 70 seat category.

\section{Competitors}

Three years after the establishment of BMW Rolls-Royce GmbH, MTU of Germany and SNECMA of France and their respective American partners came together to form a rival engine consortium. 'Project Blue' (Pletschacher and Kanebo, 1993, p24) was announced to the world at the Paris air show in 1993. Like BMW Rolls-Royce $\mathrm{GmbH}$, Project Blue aimed to develop an engine family in the 12,000-23,000lbs thrust range. The four companies felt that the potential of this market segment was too great to be left to BMW Rolls-Royce GmbH (Mecham, 1993, p49). However they planned to develop an engine towards the top of this thrust range first, since BMW RollsRoyce $\mathrm{GmbH}$ had initially focussed on the lower end. Unfortunately the partners were unable to agree on the detail of the engine specification and within a year the consortium had collapsed.

Unable to agree on the best path to develop a competitor engine that would rival BMW Rolls-Royce GmbH's offerings, members of the 'Gang of Four' (Pletschacher and Kanebo, 1993, p24) who had set up Project Blue tried again.

France's SNECMA joined forces with Pratt and Whitney's small engine subsidiary Pratt and Whitney of Canada. In April 1996 they announced plans to develop a new 12,000-16,000lbs thrust engine, the SPW14, that would compete with the smaller of the two BMW Rolls-Royce GmbH engines, the BR710. The SPW14 was to be based on the core of SNECMA's M88 military engine. Although it won the technical evaluation for the $\mathrm{AI}(\mathrm{R}) 70$ regional jet, the project was shelved. Plans for a stretched SPW14 were announced in March 1999, with the thrust rating extended to 20,000lbs thrust. Despite the fact that this expanded the number of potential applications, by the end of the 1990s the joint venture remained stillborne as it lacked a launch airframe. 
Meanwhile in 1997 Pratt and Whitney announced plans to go it alone in developing a rival to the BR700, with the launch of an entirely new engine the PW6000 (Donaghue, 1998). With a thrust rating of $15,000-20,000 \mathrm{lbs}$, the PW6000 scored an early success when in September 1998 it was designated the launch engine for the new Airbus regional airliner, the 100 seat A318. However Pratt and Whitney was not able to secure single sourcing on the A318. CFM-International with a de-rated version of its highly successful CFM56 engine became an alternative supplier when Air France ordered 15 CFM56 powered A318s in July 1999 (Lewis, 1999). Nor was this Pratt and Whitney's only problem with the PW6000. Technical problems with the engine meant that instead of the projected entry into service date of the PW6000-powered A318 being 2003, this had to be put back a year (Lewis, 2002). This was a most inauspicious start for a major new engine programme.

The same could not be said of the fourth engine to rival BMW Rolls-Royce GmbH's BR700, General Electric's CF34 engine. This engine pre-dated BMW Rolls-Royce $\mathrm{GmbH}$ by some 20 years and at the time of the launch of the joint venture was not a competitor. The CF34 was a commercial derivative of the military TF34 engine developed by General Electric in the late 1960s to power the Fairchild-Republic A10 Thunderbolt fighter-bomber. Much smaller than either of the BR700 engines, the commercial CF34 engine was developed from the military TF34 in the 1980s and found applications on medium-sized corporate jets. However in the late 1990s the CF34 emerged as a rival to the BR700 when General Electric successfully developed much more powerful versions, first of $13,000 \mathrm{lbs}$ thrust and then $18,000 \mathrm{lbs}$ thrust. It became a serious competitor for the BR710 engine as the manufacturers of small regional jets developed larger 70-90 seat models. As the leading manufacturers of regional jets of this size, including Bombardier and Embraer, opted for the high thrust versions of General Electric's engine, the CF34 found a ready market and sales soared.

\section{COMPETITIVE STRATEGIES OF THE PARTNERS}


Although one of the features of BMW Rolls-Royce GmbH is that it is was an equity joint venture and therefore independent of its parents, the evaluation of the performance of the joint venture has to take account of the partners and their motives in setting it up. Establishing BMW Rolls-Royce $\mathrm{GmbH}$ was a major step for both of the partner companies. It formed an important element in each company's competitive strategy. Hence evaluation of the joint venture needs to consider the contribution that it made to the competitive strategies of each partner.

\section{BMW AG}

At the time the joint venture was established in 1990, BMW was an independent specialist car manufacturer focused on a specific market niche - executive saloons (Noble, 1992). It was one of five smaller specialist car manufacturers in Europe (Womack, et. al., 1990) alongside Mercedes, Volvo, Saab and Jaguar. Although in third place in terms of output among Germany's automotive manufacturers, behind Daimler-Benz, and VW, BMW was highly profitable. Positioned between the full range car manufacturers (Noble, 1992) and the craftsmen built output of the luxury saloon manufacturers (Kay, 1999), BMW successfully matched the organisation's distinctive capabilities - German engineering and technical expertise, to the market opportunities presented by high performance saloon cars. In the process BMW had become a world leading, highly valued brand. In Kay’s (1999, p18) words “ $B M W$ proved to be one of the great success stories in modern business history".

BMW in 1990 differed markedly from most other car manufacturers. Not only was it much more focussed in the sense that its products targeted a narrow market segment it was also much more focussed on car production, having undertaken little in the way of diversification. This was in sharp contrast to its competitors, most of whom had non-car interests, particularly in the field of aerospace. All the major American car producers, General Motors, Ford and Chrysler, had aerospace divisions. Not only that, some extended their exposure to aerospace in the 1980s. General Motors purchased Hughes Electronics in 1985, in a move intended to reduce its dependence on cars (Hayward, 1994), and in the same year Chrysler sought to increase its diversification through the purchase of Gulfstream Aerospace (Phillips, Phillips and 
Phillips, 1994). In Europe, Volvo, Saab and Fiat all had established aerospace divisions. During the 1980s Daimler-Benz spent DM 8 billion diversifying into aerospace, defence and electronics. Under its chairman, Edzard Reuter, it had built up a major aerospace division through its acquisition of MTU, Dornier, MBB and Fokker. From being almost exclusively a builder of prestige cars and trucks, DaimlerBenz rapidly evolved during the 1980s into an industrial conglomerate whose aerospace division formed the bulk of the German aerospace industry. Diversification into aerospace was also a feature of car producers in the Far East. Japanese car manufacturers Mitsubishi and Nissan had major aerospace divisions. Even in Korea firms new to car manufacturing like Hyundai and Daewoo had interests in aerospace. Against this background, BMW, was unusual. Its strategy had been to focus on the automotive sector, rather than diversifying.

By 1990 BMW had reached an awkward size (Allison and Barnes, 1993). Its sales had grown steadily during the 1980s. By 1990 it had a turnover of DM 27 billion and was producing half a million cars per year. Although still substantially smaller than the full range producers, such as Fiat and Renault (table IV), it was large for a specialist manufacturer producing cars for a specific market niche. Although pursuing its market niche on a global basis helped, it was in danger of becoming a victim of its own success. Sales growth reduced the exclusivity sought by buyers in this market segment and associated with the BMW brand.

\section{Take in Table IV}

Consequently diversification into aerospace through a strategic alliance with Britain's Rolls-Royce had a number of attractions as a competitive strategy. Firstly, it was in line with the competitive strategies being pursued by competitors, many of whom had also diversified into aerospace. Secondly it was likely to reinforce rather than dilute the brand (Kay, 1993). Finally it had the appeal of enabling the company to return to its roots as an aero engine manufacturer.

In meeting these ambitions, a strategic alliance with Rolls-Royce measured up well. When the first engines left the joint venture's engine plane at Dahlewitz, near Berlin 
in 1996, BMW regained its status as an aerospace company. Aero engines, as high technology products complemented BMW's increasingly sophisticated range of cars. Although the joint venture had required a big investment to develop an entirely new engine, the technical performance of the engine was satisfactory and overall sales were on target.

Why then did BMW withdraw from the joint venture in 1999? The answer lies not in BMW's aero engine activities but rather in its car division. Four years after establishing the joint venture with Rolls-Royce, BMW announced much bolder plans when in 1994 it bought the British car manufacturer Rover. Despite early promise, this venture became mired in crisis when, as table V shows, Rover sales fell sharply in the first half of 1999.

\section{Take in Table V}

The drop in sales was attributed to the high value of the pound and changes in Rover's product range. The effect was a sharp decline in Rover's market share to 4.6 per cent. These troubles were widely reported in the press and led to the departure of BMW's chief executive Bernd Pischetsreider and his deputy Wolfgang Reitzle. The company was forced to turn all its efforts to turning Rover around. Under these circumstances, it was perhaps not surprising that BMW chose to focus its efforts on its core business and turn its investment in aero engines into a more liquid form.

There were other factors beside this immediate short term crisis that led BMW to focus on its core business. The car industry, especially the sector inhabited by BMW was very different at the end of the 1990s from what it had been at the start of the decade. Whereas there had been five European firms in the specialist executive car market segment at the start of the decade, none remained as independent producers by the end of the decade. Having taken over Rover, BMW doubled in size in output terms and moved into the volume car sector. British owned Jaguar was bought by Ford of the US in 1990. In the same year General Motors of the US bought a 50 per cent stake in Sweden's Saab exercising its option to buy the remainder in January 2000. In 1998 Daimler-Benz, manufacturers of Mercedes cars, merged with Chrysler 
of the US and finally in 1999 Ford of the US bought Volvo's car division for \$5 billion. In the course of a decade the executive car market segment was transformed. Independent specialist manufacturers of executive cars disappeared, unable to sustain the $\$ 1$ billion costs associated with developing a new model. Instead they became part of volume car manufacturers whose competitive strategy was to cease selling executive cars under a generic name, in favour of buying or building an executive car brand. In the process they stood to benefit from economies of scope.

BMW was at the centre of this strategic change. It acquired a volume car business that included three major UK plants and it established manufacturing facilities in the US. Faced with such dramatic strategic change, it chose to focus on its core business.

In opting to focus, BMW was not alone. A clear trend of the 1990s was a move away from diversification by the leading car makers. In 1990 Ford sold its Ford Aerospace division to Loral which was in turn purchased by Lockheed-Martin in 1996. General Motors of the US, sold its Allison aero engine division in 1993 and then in 1996 sold its Hughes Electronics division to Raytheon. Similarly, US car maker Chrysler, sold its Gulfstream aerospace business in 1990, when 'an anticipated synergism between the companies never materialised' (Phillips, Phillips and Phillips, 1994, p225). Similarly in Europe, British Aerospace and Saab sold their car businesses in the early 1990s in order to concentrate on aerospace. The drive to focus was not driven by car makers failing to make a success of aerospace. Ford Aerospace for instance, had been consistently profitable (Hayward, 1994). However, the harsher environment for defence contractors that prevailed in the years after the ending of the Cold War, caused car makers like General Motors, Ford and Chrysler to re-evaluate their strategy and exit from the aerospace business.

Hence, by the end of the 1990s the car industry environment, especially the executive car segment looked very different from a decade earlier. When combined with BMW's problems with its Rover division and BMW Rolls-Royce GmbH's relatively slow progress in the rapidly developing regional jet market, it was perhaps inevitable that BMW should re-evaluate its involvement in the aero engine business. 
In October 1999 BMW sold its share in BMW Rolls-Royce GmbH to its British partner and the enterprise was re-named Rolls-Royce Deutschland. The move was a direct result of problems in BMW's car division rather than dissatisfaction over the company's decade long venture in aerospace. This was reflected in BMW's decision to increase its stake in Rolls-Royce from $2 \%$ to $10 \%$, a move designed to demonstrate the company's confidence in the aerospace activities to which it had been party.

\section{Rolls-Royce plc}

By 1990 Rolls-Royce was one of only three aero engine manufacturers in the world with the capability to design, develop and manufacture a range of military and civil aero engines (Hayward, 1989). It had only recently returned to the private sector having been floated in May 1987 as part of the Thatcher administration's privatisation programme.

\section{Take in Table VI}

After the financial disaster in the early 1970s, that had seen the company taken into public ownership and its car division sold to Vickers, it had made significant progress during the 1980s. Not only had its sales risen steadily (table VI), but it had returned to profit. A major factor had been a drive for improved productivity which had seen the company lose 26,000 jobs in six years (Hayward, 1989). It had also reduced its dependence on its biggest customer, the UK government. The proportion of civil engines that made up the company's output rose steadily (table VI). Its share of the market for civil engines, which had averaged 13 per cent in the late 1970s and early 1980s (Hayward, 1989), had risen to 20 per cent by 1990. This reflected an increasing emphasis on commercialisation within the company. Thus by 1990 Rolls-Royce was much healthier than it had been a decade earlier. Not only was it back in profit but it had an order backlog of $\$ 5.7$ billion.

However, Rolls-Royce faced a number of weaknesses. Although one of the Big Three engine manufacturers in the world, in terms of size as measured by turnover, which stood at $\$ 4.1$ billion in 1990 , it was almost half the size of its two American rivals, 
General Electric with a turnover of $\$ 7.6$ billion and Pratt and Whitney with a turnover of $\$ 7.3$ billion.

Not only was it in third place, the company was heavily committed to the development of two major new engine programmes. The V2500 engine being developed as part of the International Aero Engines joint venture was about to enter service, but was not projected to break-even until 2001 (Birch, 1998). The company had launched its biggest and most expensive engine, the Trent, two years earlier in 1988 (Walters, 1999). Not only was the Trent absorbing a great deal of money for research and development, it was several years away from entering service let alone contributing to profitability.

Unlike its American counterparts, Rolls-Royce was not a diversified industrial group. It had begun to diversify having moved into power generation through the acquisition of Northern Engineering Industries in 1989, but was still heavily dependent on aerospace. This made it vulnerable to the cyclical nature of the aerospace industry that led to strong fluctuations in sales. This was normally mitigated by military sales which were more stable, but the ending of the Cold War brought this in to question.

However Rolls-Royce's biggest weakness was the narrowness of its product range. In 1980 the company was able to offer engines for just four civil aircraft applications (Rolls-Royce 1997, p8). This put Rolls-Royce at as serious disadvantage. Firstly, it meant that there were some market segments in which Rolls-Royce simply did not compete. This made the company vulnerable because a downturn in the segments where it was represented could not be offset against segments where demand remained healthy. Secondly since commercial airliner manufacturers operate across all market segments and plan their engine acquisition strategies in an integrated manner, they tend to favour suppliers with a full range product portfolio (Bonaccorsi and Giuri, 2000, p859). Thirdly, in the jet engine sector of the aero engine market, a failure to cover a broad range of market segments means that a manufacturer is unable to take advantage of the economies of scope which come from offering a range of engines that share the same technology (Bonaccorsi and Giuri, 2000, p867). Rolls- 
Royce was loosing the potential increasing returns from R \& D that it would have gained with a broader product range.

Mindful of these weaknesses, Rolls-Royce in the 1980s defined a new competitive strategy that was to alter both the company and the way in which it did business. The company set the ambitious goal of a 30 per cent share of the worldwide civil turbofan market. In view of the company's modest share of the market at this time and the dominant position of Pratt and Whitney, this was a particularly ambitious goal.

In order to meet its long term goal, Rolls-Royce's competitive strategy from the early 1980s onwards was ‘to broaden its civil aero engine product range' (Pugh, 2001, p325). A broader product range not only increased the number of market segments in which the company could compete, it also provided scope for 'making technology transferable between engines' (Pugh, 2001, p324).

As part of this strategy Rolls-Royce developed a number of derivative engines. These utilized the core of an existing engine adapted, often using new technologies developed for other engines, to meet the needs of a new market segment. Examples of this derivative approach included the 535 engine which entered service in 1983, a derated version of the larger RB-211 and the Tay which entered service in 1987, based on the core of the Spey engine of the early 1960s. While the derivative approach enabled Rolls-Royce to extend its product portfolio for a much reduced outlay compared to completely new engine designs, it had its limitation. Consequently in the late 1980s Rolls-Royce utilized another mechanism for extending its portfolio, namely strategic alliances.

BMW Rolls-Royce GmbH was one such alliance. To judge by the progress that Rolls Royce made in achieving its long term goals, BMW Rolls-Royce GmbH may be judged very successful. By the end of 1999, when the joint venture was concluded, Rolls-Royce was in vastly better shape.

The company's annual report for that year (Rolls-Royce, 2000, p3) noted that the company had achieved its long term goal of a 30 per cent share of all civil aero engine 
orders for each of the last three years. The company's product portfolio was by this time much broader with company supplying engines for 30 different civil airframe applications. A measure of the progress that had been made since the inception of BMW Rolls-Royce GmbH can be gauged from the fact that the increase in airframe applications represented 'a five-fold increase compared to the position at the start of the 1990s' (Rolls-Royce, 2000, p10). BMW Rolls-Royce GmbH was responsible for four of the additional airframe applications.

\section{Take in Table VII}

Improvements in market share were reflected in a big increase in engine production during the course of the 1990s. Table VII shows that over the course of the 1990s output of civil aero engines rose steadily. Output rose especially rapidly after 1996 when the first BMW Rolls-Royce GmbH engines went into service. Although the growth in output was brought about by a number of factors, including the build up of Trent engine production and growth in small engine production, BMW Rolls-Royce $\mathrm{GmbH}$ was clearly an important contributor.

\section{CONCLUSION}

Given that the joint venture was terminated in November 1999, after almost a decade of existence, one might expect any evaluation of BMW Rolls-Royce $\mathrm{GmbH}$ to conclude that it was not a success. If continuity and longevity are evaluation criteria then this would appear to be the case. However the fact that aero engines continue to be produced at the joint venture's premises at Dahlewitz near Berlin, suggests that such a judgement might be unwarranted.

Evaluating a strategic alliance from a strategic management perspective is primarily a matter of determining the extent to which the collaboration achieved the long term objectives of the partners who set it up. In the case of BMW Rolls-Royce GmbH the objective was simple enough, The partners, BMW and Rolls-Royce, set out to produce a family of advanced turbofan engines, based on an entirely new engine core, that would compete in the 14,000-22,000lbs thrust segment of the market. 
Though straightforward, this was an ambitious target for two reasons. Firstly, new engines, especially those that are new designs, take a very long time to develop. Many have taken nearly ten years to get them into full scale production. Over such a long time scale market conditions can change dramatically. Secondly, the market for the new engine was far from clear. None of the aircraft that the BR700 engine was intended for, was yet in service. The prospects for the regional airliner market especially were far from clear, with a number of aircraft proposed, but not actually launched as committed programmes.

Against this background, BMW Rolls-Royce GmbH would appear to have performed remarkably well. The new engine core that formed the basis of both the BR700 engines was a technical success. Unlike many engine programmes, especially those that are new rather than derivative designs (Gunston, 1989), both BR700 engines encountered few technical problems and exceeded their performance targets in service. Similarly sales were encouraging and are currently on target to meet the long term level of sales projected for 2010.

One aspect of the strategic alliance's performance qualifies the picture of strong performance. The larger of the two engines, the BR715, has not sold as well as planned. This is largely because the regional jet market has not developed as predicted back in 1990. While there has been a 'rush for jets', growth has occurred in the 50 and 70 seat sectors, with demand for the larger 100 seat regional jets remaining sluggish.

As for the partners who created the strategic alliance, the picture is mixed. The fact that BMW pulled out in 1999strongly suggests that the joint venture did not measure up to the German car makers's expectations. However as this study has shown, such a conclusion would be premature. For one thing BMW has retained a financial interest, albeit through its stake in Rolls-Royce rather than the joint venture itself. More significantly, changes in the automotive industry over the course of the 1990s, especially those associated with the competitive strategies of most of the leading car makers, have meant that BMW has chosen to focus on its automotive interests. 
As for Rolls-Royce, it has clearly benefited greatly from the collaboration. It now has a much broader product portfolio than a decade ago. The company has achieved its long term goal of a one third share of the commercial jet engine market and it has overtaken its long time rival Pratt and Whitney, moving up into second place among the world's leading aero engine producers. The alliance with BMW played an important part in the company's improved performance.

Thus from both the perspective of the partners and the joint venture itself, an evaluation of BMW Rolls-Royce GmbH really has to conclude that it performed well and was remarkably successful over the decade or so of its existence. 


\section{REFERENCES}

Allison, R and Blum, E (1993) "BMW: niche marketing in a global economy", in J Preston (ed.) International Business: Text and Cases, Pitman.

Birch, D (1998) “International Thrust” Air International Vol 54, No 6, pp. 367-369.

BMW (1998) BMW Annual Report 1997, BMW AG, Munich.

BMW (1999) BMW Annual Report 1998, BMW AG, Munich.

Bonaccorsi, A. and Giuri, P. (2000) "When shakeout doesn't occur: The evolution of the turboprop engine industry", Research Policy, Vol 29, pp. 847-870.

Dixon, T. (2000) “Setting the Standard: Bombardier's Regional Jet”, Airliner World, August 2000, pp62-69

Donoghue, J A (1998) “Cheap is good”, Air Transport World, August 1998, pp 50-58.

Dussauge, P and Garrette, B (1993) 'Industrial Alliances in Aerospace and Defence: An Empirical Study of Strategic and Organisational Patterns", Defence Economics, Vol 4, pp. 45-62.

Dussauge, P and Garrette, B (1994) "Alliances industrielles dans les secteurs de l'aerospatiale et de la defense", in Noel, A., Perspectives en Management Strategique, Tome I, 1992/93.

Dussauge, P and Garrette, B (1995) "Determinants of success in Industrial Strategic Alliances: Evidence from the Global Aerospace Industry", Journal of International Business Studies, Vol 26, No 3, pp. 505-530.

Dussauge, P and Garrette, B (1999) Cooperative Strategy: Competing Successfully through Strategic Alliances, John Wiley and Sons Ltd, Chichester.

European Commission (1997) “The European Aerospace Industry”, European Commission, Brussels.

Flight International (1992) “Aerospace Top 100”, 19-25 August 1992, pp. 31-57.

Flight International (2000a) “Aerospace Top 100”, 18-24 July 2000, pp. 43-65.

Flight International (2000b) “Regional Jet Survey”, 24-30 October 2000, pp. 43-66.

GAMA (2001) “Shipment Report Year End 1997-2000”, 7 February 2001, General Aviation Manufacturers Association, Washington, D.C.

Glaister, K W and Buckley, P J (1994) "UK International Joint Ventures: An Analysis of Patterns of Activity and Distribution", British Journal of Management, Vol 5, No 1, pp. 33-52. 
Gomes-Casseres, B. (1996) The Alliance Revolution: The New Shape of Business Rivalry, Harvard University Press, Cambridge, Mass.

Gunston, B (1989) Rolls-Royce Aero-Engines, Patrick Stephens Ltd, Sparkford.

Hanlon, P (1999) Global Airlines: Competition in a Transnational Industry, $2^{\text {nd }}$ edition, Butterworth-Heinemann: Oxford.

Hartley, K. (1983) NATO Arms Collaboration: A Study in Economics and Politics, George Allen and Unwin.

Hartley, K. 1988) 'Aerospace: The Political Economy of an Industry' in H.W. de Jong (ed.) The Structure of European Industry, $2^{\text {nd }}$ edition, Kluwer Academic Publishers.

Hartley, K. and Martin, S. (1990) "Collaborative projects: International collaboration in aerospace”, Science and Public Policy, Vol 17, No 3, pp. 143-151

Hartley, K. and Martin, S. (1993) "Evaluating Collaborative Programmes" Defence Economics Vol 4, No 2, pp.195-211

Hayward, K (1976) "Politics and European Aerospace Collaboration; The A300 Airbus", Journal of Common Market Studies, Vol 14, pp. 354-367.

Hayward, K (1986) International Collaboration in Civil Aerospace, Pinter.

Hayward, K (1989) The British Aircraft Industry, Manchester University Press, Manchester.

Hayward, K (1994) The World Aerospace Industry: Collaboration and Competition, Duckworth.

Hegert, M and Morris, D (1987) 'Trends in international collaborative agreements', Columbia Journal of World Business Vol 22, pp. 15-21.

Kay, J (1993) Foundations of Corporate Success, Oxford University Press, Oxford.

Kay, J (1999) 'A takeover that missed the mark' Financial Times 18th February 1999 p 18.

Kinnear, I. (1986) "Tay certificated and soon to enter service”, The Rolls-Royce Magazine, September 1986, pp. 20-24.

Kingsley-Jones, M.. (2001a) "Airframers: No pain in prospect as cycle gently touches bottom” Flight International, 2-8 January 2001, p. 28.

Kingsley-Jones, M.. (2001b) "BR715 offered for MD80" Flight International, 24-30 July 2001, p. 10. 
Lewis, P. (1999) “CFMI scoops second slot on A318” Flight International, 21-27 July 1999, p4.

Lewis, P. (2002) “CFM56 takes pole position on A318” Flight International 22-28 January 2002, p. 5.

Martin, S. and Hartley, K. (1991) "European collaboration in aerospace: recent trends and future prospects", European Research, Vol 2, Part 6, November, pp. 1419.

Martin, S. and Hartley, K. (1995) "European Collaboration in Civil Aerospace: Success or Failure?” Journal of Common Market Studies, Vol 32, No 2, pp. 275-291.

McGuire, S. (1997) Airbus Industrie: Conflict and Cooperation in US-EC trade Relarions, Macmillan Press, Basingstoke.

Mecham, M. (1993) "Engine Makers Collaborate on New Small Jet Family", Aviation Week and Space Technology, 21 june 1993, pp. 49-50.

Monnich, H (1991) The BMW Story: A Company in its Time, Sidgewick and Jackson

Moorman, R.W. (1997) “Fan Watch”, Air Transport World, No 5, pp.31-42.

Mowery, D C (1987) Alliance politics and economics: Multinational joint ventures in commercial aircraft, Ballinger, Cambridge: MA

Mowery, D C (1988) "Joint ventures in the US Commercial aircraft Industry", in Mowery, D C (ed.) International Collaborative Ventures in US Manufacturing, Ballinger, Cambridge, MA.

Muller, P (1995) "Aerospace Companies and the State in Europe" in Hayward, J. (ed.) Industrial Enterprise and European Integration: From National to International Champions in Western Europe, Oxford University Press, Oxford.

Noble, D (1992) "Industry Dynamics in Europe: The Motor Industry" in Young, S. Hamill, J. (eds.) Europe and the Multinationals: Issues and Responses for the 1990s, Edward Elgar, Aldershot.

Norris, G., Kingsley-Jones, M. and Doyle, A. (2001) "Climbing the learning curve", Flight International, 2-8 June 1999, pp. 42-48

Pletschacher, P. and Kanebo, S.W. (1993) "Project Blue may launch JT8D successor", Aviation Week and Space Technology, $8^{\text {th }}$ November 1993, p24.

Phillips, A, Phillips, A M and Phillips, T R (1994) BizJets: Technology and Market Structure in the Corporate Jet Aircraft Industry, Kluwer, Dordrecht. 
Pugh, P. (2001) The Magic of a Name, The Rolls-Royce Story Part Two: The Power Behind the Jets, Icon Books, Duxford, Cambridge

Rolls-Royce (1997) Annual Report 1996, Rolls-Royce plc, London.

Rolls-Royce (2000) Annual Report 1999, Rolls-Royce plc, London.

Rupertson, F (1998) “Gulfstream V” Air International Vol 55, No 4, pp. 221-227.

Thornton, D.W. (1996) Airbus Industrie: The Politics of an International Industrial Collaboration, St. Martins Press, New York.

Very, P, Berthelier, M and Calori, R (1993) 'A note on the world automobile industry' in G Johnson and K Scholes Exploring Corporate Strategy, 3rd Edition, Prentice Hall, pp. 558-570.

Walters, B (1998) “Rolls’ biggest fan”, Air International Vol 56, No 2, pp. 115-118.

Womack, J P, Jones D T and Roos, D (1990) The Machine that Changed the World, Rawson Associates: New York. 


\section{Tables and Figures}

\section{Table I}

Turnover of European Aero Engine Manufacturers 1990-9

\begin{tabular}{lllrr} 
Rank & Organisation & Country & \multicolumn{2}{c}{ Turnover (\$m) } \\
\hline & & & 1990 & 1999 \\
1. & Rolls-Royce plc & UK & 4,153 & 6,107 \\
2. & SNECMA* & France & 2,969 & 3,962 \\
3. & MTU & Germany & 2,229 & 1,853 \\
4. & Fiat Avio* & Italy & 1,328 & 1,517 \\
5. & Volvo Flygmotor* & Sweden & 402 & 1,801 \\
6. & BMW Rolls-Royce GmbH & Germany/UK & $\mathrm{n} / \mathrm{a}$ & 727 \\
7. & Turbomeca & France & 544 & 534 \\
* also & manufacture non-engine sub-systems and components &
\end{tabular}

Source: Flight International (1992); Flight International (2000a).

\section{Table II}

Growth of BMW Rolls-Royce GmbH 1993-99

\begin{tabular}{lrrrrrrr} 
& $\mathbf{1 9 9 3}$ & $\mathbf{1 9 9 4}$ & $\mathbf{1 9 9 5}$ & $\mathbf{1 9 9 6}$ & $\mathbf{1 9 9 7}$ & $\mathbf{1 9 9 8}$ & $\mathbf{1 9 9 9}$ \\
\hline Turnover (\$million) & 73 & 68 & 73 & 144 & 339 & 452 & 727 \\
Investment (\$million) & 103 & 148 & 108 & 195 & 61 & 72 & $\mathrm{n} / \mathrm{a}$ \\
Employees & 1,200 & 1,450 & 1,800 & 1,957 & 2,065 & 2,066 & n/a
\end{tabular}

Source: BMW (1998); BMW (1999). 
Table III

Orders/Deliveries for the Boeing 717/MD-95

Airline Delivered On Order Total

\begin{tabular}{lrrr}
\hline Aerolineas Baleares & 4 & 0 & 4 \\
AirTran Airways & 22 & 28 & 50 \\
Bangkok Airways & 2 & 0 & 2 \\
Bavaria Leasing & $(5)$ & 0 & $(5)$ \\
Hawaiian Airlines & 4 & 9 & 13 \\
Impulse Airlines & 8 & 0 & 8 \\
Olympic Aviation & 3 & 0 & 3 \\
Pembroke Capital & $(6)$ & 21 & 21 \\
Turkmenistan Airlines & 0 & 3 & 3 \\
TWA & 20 & 30 & 50 \\
& 63 & 91 & 154
\end{tabular}

Source: Norris, Kingsley-Jones and Doyle (2001)

Table IV

European Car Market in 1990

\begin{tabular}{llcr} 
& Manufacturer & $\begin{array}{c}\text { Output } \\
(\mathbf{0 0 0 s})\end{array}$ & $\mathbf{\%}$ \\
\hline 1. & VW & 2,031 & 15.4 \\
2. & Fiat & 1,874 & 14.2 \\
3. & PSA & 1,708 & 12.9 \\
4. & General Motors & 1,554 & 11.8 \\
5. & Ford & 1,529 & 11.6 \\
6. & Renault & 1,295 & 9.8 \\
7. & Daimler-Benz & 431 & 3.3 \\
8. & Rover & 390 & 2.9 \\
9. & Nissan & 381 & 2.9 \\
10. & BMW & 362 & 2.7
\end{tabular}

Source: Very, Berthelier and Calori (1993) 


\section{Table V}

Output of BMW Group 1998-99

\begin{tabular}{lrrr} 
Date & January-June 1999 & January-June 1998 & Change \\
\hline Cars & 562,952 & 630,491 & $-10.7 \%$ \\
BMW & 381,689 & 350,596 & $+8.9 \%$ \\
Rover & 87,459 & 173,376 & $-49.6 \%$ \\
Land Rover & 83,511 & 89,813 & $-7.0 \%$ \\
Mini & 5,093 & 8,692 & $-41.4 \%$ \\
MG & 5,201 & 8,104 & $-35.1 \%$ \\
Motorcycles & 42,660 & 36,138 & $+18.0 \%$ \\
Aero engines & 71 & 51 & $+39.2 \%$
\end{tabular}

Source: BMW (1999).

Table VI

Rolls-Royce Distribution of Turnover 1982-87

\begin{tabular}{lllll} 
Year & Civil & Military & Other & Total \\
\hline 1982 & 520 & 742 & 231 & 1,493 \\
1983 & 388 & 706 & 137 & 1,331 \\
1984 & 446 & 735 & 228 & 1,409 \\
1985 & 577 & 735 & 289 & 1,601 \\
1986 & 757 & 740 & 305 & 1,802 \\
1987 & 943 & 820 & 286 & 2,059
\end{tabular}

Source: Hayward (1989)

Table VII

Rolls-Royce Annual Civil Aero Engine Output 1994-99

\begin{tabular}{cr} 
Year & Output \\
\hline 1994 & 407 \\
1995 & 405 \\
1996 & 424 \\
1997 & 625 \\
1998 & 911 \\
1999 & 1089
\end{tabular}

Source: Rolls-Royce (2000). 
Figure 1

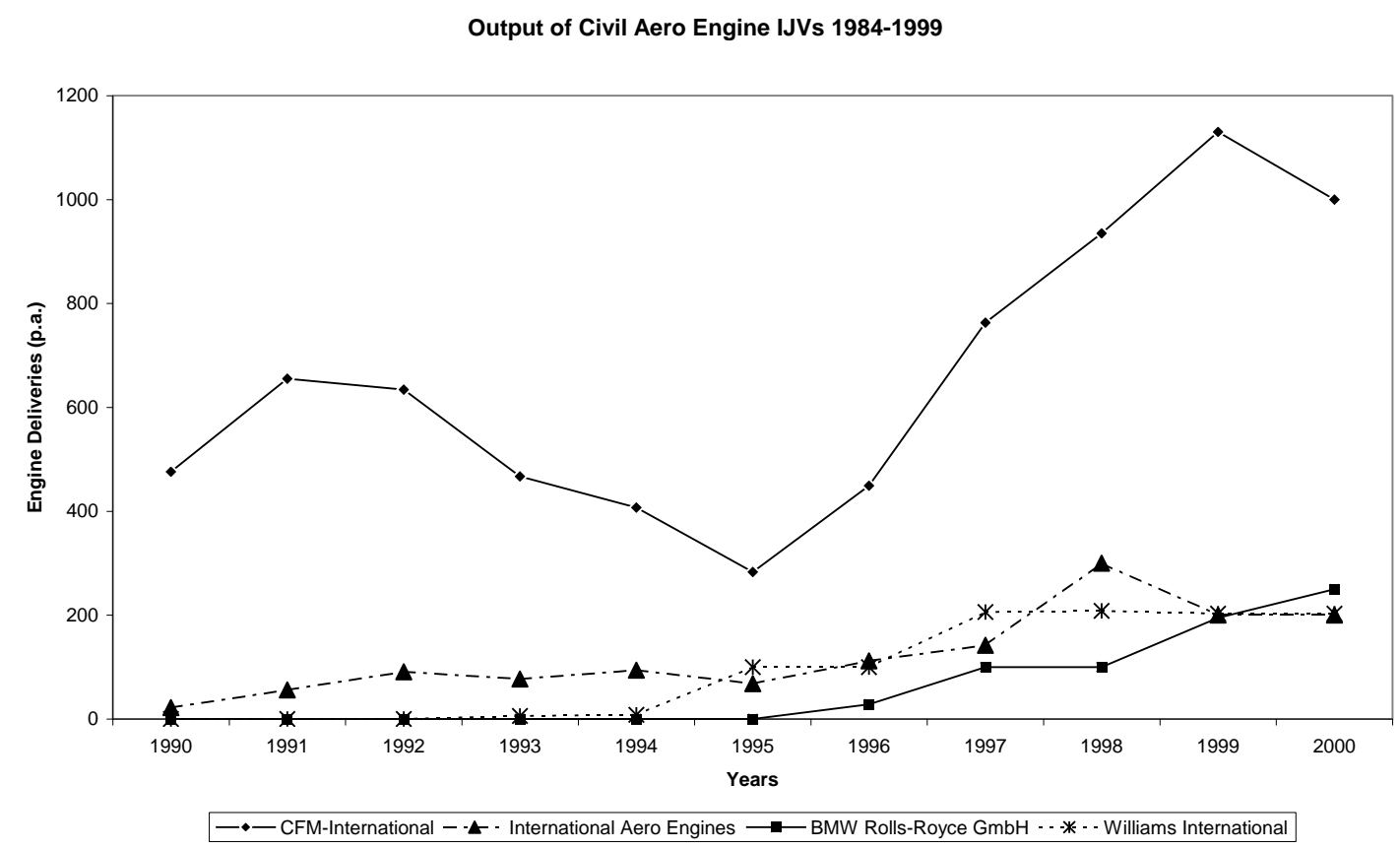

Source: European Commission (1997); GAMA (2001) 
Figure 2

Regional Airliner Market 1991-2001

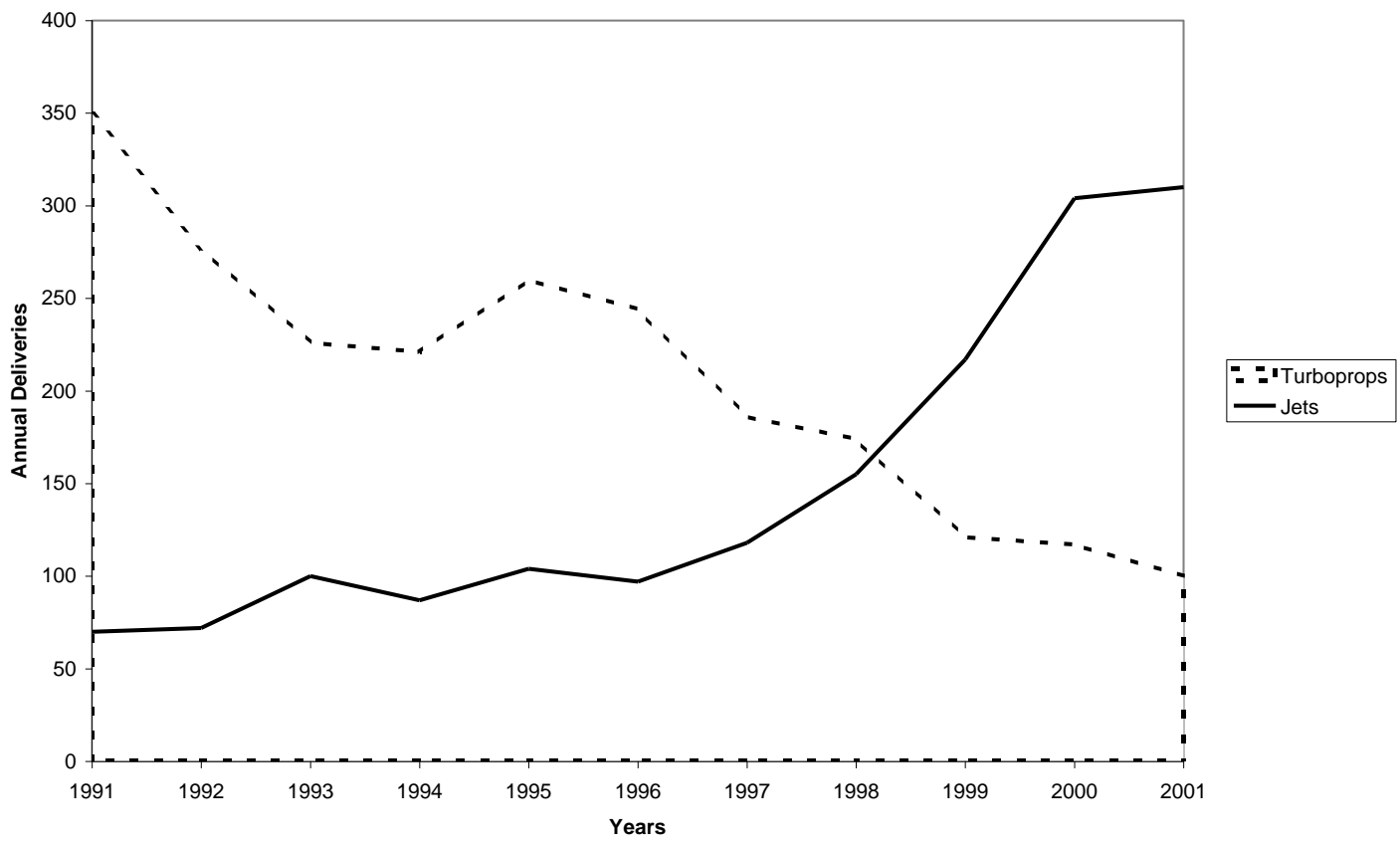

Source: Kingsley-Jones (2001a); 